\title{
新規育成米の利用特性
}

\author{
大坪 研 * $^{*}$ 中川原捷洋 ${ }^{* *}$ ・岩崎哲也*
}

\section{Utilization Suitabilities of New Endosperm Characters of Rice Strains}

\author{
Ken' ichi Ohtsubo*, Masahiro Nakagahra ${ }^{* *}$ and Tetsuya Iwasaki ${ }^{*}$ \\ *National Food Research Institute, Ministry of Agriculture, Forestry \\ and Fisheries, Tsukuba, Ibaraki 305 \\ ${ }^{* *}$ National Institute of Agrobiological Resources, Ministry of \\ Agriculture, Forestry and Fisheries, Tsukuba, Ibaraki 305
}

\begin{abstract}
Utilization suitabilities of the three strains, ge (giant embryo), $d u$ (dull endosperm) and $w x$ (glutinous endosperm) of rice (Oryza sativa L.) newly bred at National Institute of Agrobiological Resources, were investigated. SDS-PAGE of the milled rice proteins extracted into $62.5 \mathrm{mM}$ tris-HCl buffer $(\mathrm{pH} 6.8,2 \%$ SDS, $5 \%$ 2-ME) was carried out by the method of LAEMMLI using $8 \%$ acrylamide gel. More than 40 clear protein bands were detected by CBB staining, but electrophoretic pattern showed marked similarity of these strains. Therefore, it seemed necessary to develop a fractionation method of proteins or other useful staining to distinguish the different strains. Giant embryo mutant bearing ge locus had remarkably large embryo, and contained as much as $3.3 \%$ of crude fat in the milled rice. After polishing by an abrasive-type milling machine, a part of the embryo remained, which is profitable from a nutritional viewpoint. By the use of a friction-type milling machine, embryo was removed perfectly, which led to milling yield of $85 \%$. Its amylose content was rather high $(21.6 \%)$, and its properties were similar to those of typical non-glutinous rice varieties in regard to puffing suitability or the cooked rice texture. Glutinous endosperm mutant bearing $w x$ locus manifested the similar properties with the usual glutinous rice varieties. Most of starch was liquified by puffing, $w x$ mutant seemed suitable for a material for porriage or soup. Dull endosperm mutant bearing $d u$ locus showed intermediate processing suitabilities between glutinous and non-glutinous rice, because its amylose content was $10.9 \%$. The rice grains of the dull strain was a little chalky, and the texture of the cooked rice was similar to those of glutinous varieties. Gelatinization temprature on amylography of the dull mutant was rather higher than usual glutinous rice, and peak viscosity was about $50 \%$ of usual non-glutinous rice. Dull mutant, then, was found to be suitable for puffing because it expanded well without any excess liquification of starch.
\end{abstract}

(Rececived Jun. 15, 1987)

近年，わが国においては，米の生産能力に比べて，消 費量が少ないために，水田転作が実施されている，経済 カの向上や，食生活の変化に対応して，米の消費が減少 傾向にあるためである”が，海洋国家である我が国は，
一旦緩急があれば，食糧輸送の途絶する恐れもあり，狭 小な耕地を有効かつ連続的に利用して食糧を確保する上 からむ, 水田の確保, 食鋉自給率の向上が必要之考えら れる，そうした観点加ら，多収穫品種の育成や，栽培技

*農林水産省食品総合研究所（干 305 茨城県つくば市観音台 2-1-2)

**農林水産省農業生物資源研究所（干 305 茨城県つくば市観音台 2-1-2） 
術の改良と並んで，特徴的な品種特性を有する米を育成 し，新たな米の消費を開拓することもまた，重要な意味 を有している。

農業生物資源研究所においては，世界各地の稲の遭伝 資源を収集し，その遺伝的解析を行うとともに年3)，各 種の育種技術を駆使して，新品種の菜材となる実験系統 の育成に努めている，本研究においては，植物探索導入 研究チームにおいて新たに育成された，巨大肧（遣伝子 記号 $g e)$, 中間モ千 $(d u)$, 突然变異モ千 $(w x)$ の遺 伝子をむつ 3 系統を試料とし，利用特性の試験を行った。 大村らは，これらの突然変異による新規形質米の育種に 関して，方法，新規形質米の特徴および成分育種の必要 性を詳述している4). 巨大肧系統は，米粒の形や大きさ の点では通常粒之類似しているものの，肧が大きく，重 量にして通常粒の 2 3 倍に達する，モ千系統は，従来 のモ千種と同じ外見的特徴を示し，米粒は白色不透明で 硬い，中間モ千系統は，胚乳の外観が半透明であり，系 統によって，アミロース含量と，米粒の白色透明度が異 なっており，デンプンの諸特性の異なる系統が多数得ら れる334. また，中間モ千系統之同様な低アミロース米 は, 自然界，特にビルマ，インド北東部，中国雲南地方 にも分布していることが知られている2。特に，中間モ 千突然変異体のデンプン諸特性に関しては, 奥野らが詳 細に検討しており，胚乳のデンプン特性は出穂後 3 週目 までに決定され，モ千性遺伝子（wx）とは異なる単一 の劣性主醋因子（du）によって支配されると考察して いる).

こうした，従来我が国に見られない新規な形質の米の 導入や育種は，遺伝資源の保護，多梯化の点で有益であ り，また，米の利用拡大の視点加らも意義樑いと思われ る. 従来, 育種, 栽培, 遺伝解析等の観点からの研究が 報告されているが2 ${ }^{2)}$ ，米の利用特性の面からの研究(列 はほとんど見られない，そこで，本研究においては，前 述の新規形質米の育成後代を試料とし，一般的形質，精 米特性，米飯テクスチュア，糊化および膨化特性等の利 用特性に関する検討を行い，特に中間モ千について興味 ある結果が得られたので報告する。

\section{試料および実験方法}

\section{1. 試料}

農業生物資源研究所植物探索導入研究チームで育成さ れた新規形質米中，特に有望之思われる中間モ千系統 (探系 1915)，モ千系統（探系 1918），巨大臕系統（探 系 2006）（60 年産）を試料とし，比較試料として，茨城
県産コシヒカリ，長野県産むちひかりを使用し，䖽白質 性状の比較に茨城県産日本晴, 密陽 23 号, インド産バ スマティーライスを使用した。

\section{2. 形質}

玄米の粒長，粒幅，粒厚を粒形テスターにより測定し， 千粒重を常法により求めた.

\section{3. 試料の精米および製粉}

精米は，サタケ・モーターワンパス精米機（摩擦式） およびサタケ・テストミル（研削式）により，循環回数 あるいは精米時間を変えて行い，歩留り（91\%が基準） および白度を測定して試験した，製粉は，ブラベンダー テストミルを使用し，50メッシュ笠通過を基準とした．

\section{4. 玄米および精米の透光度および白度}

理研計器（株）ライスメータ QS-101 D を使用して, 玄米および 3 項で得た精米の透光度を測定した，玄米は 通常条件で測定した，本器は玄米評価装置であり, 精米 は測定が困難である，そこで，切換スイッチを測定レン シとし，下限調節スイッチによりもちひかりを0，上限 調節スイッチによりコシヒカリを 100 と設定し，新規形 質米の相対的透光度を測定した。

玄米および精米の白度は，ケット科学（秼）の白度計 C-3 型を使用して測定した.

\section{5. 一般成分}

$91 \%$ 精米の一般成分を，常法に従って測定した. 粗 タンパク含量は, セミ・ミクロケルダール法（タンパク 質・窒素換算係数 5.95)，粗脂肪含量はエーテル抽出法， 灰分は $550^{\circ} \mathrm{C}$ 直接灰化法, 水分は $135^{\circ} \mathrm{C}, 2$ 時間乾燥法, 炭水化物は差引き法により求めた。

\section{6. アミロース含量}

JULIANO の簡易測定法 ${ }^{6)}$ により求めた. 各試料を, サタヶ・モーターワンパス精米機を使用して步留り 91 \%（巨大胚系統のみ 85\%）に精米した後，三田村理研

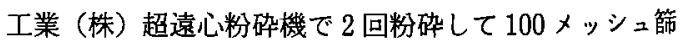
通過程度の粉末を得た．その $100 \mathrm{mg}$ を, $1 \mathrm{~m} l$ エチル アルコール, $9 \mathrm{ml}$ の $1 \mathrm{~N} \mathrm{NaOH}$ 中, $100^{\circ} \mathrm{C}$ で 10 分間 糊化させた後， $100 \mathrm{~m} l$ に希釈し，その $5 \mathrm{ml}$ に $1 \mathrm{~N}$ 酢 酸を $1 \mathrm{ml}$ 添加して中和後， $ヨ$ ード溶液（ヨウ素 $0.2 \mathrm{~g}$, ヨウ化力リ $2 \mathrm{~g} / 100 \mathrm{~m} l)$ を $2 \mathrm{~m} l$ 添加し, $100 \mathrm{ml}$ に希 釈して 20 分後に $620 \mathrm{~nm}$ における吸光度を測定した。 標準アミロースとしては，シグマ社製ポテトアミロース （Type III）を使用した.

\section{7. 精米粉のタンパク質の電気泳動}

第 3 項で得た精米粉（歩留 $91 \%$ ，ge のみ $80 \%$ ）各 $0.5 \mathrm{~g}$ を，2\% SDS，5\%メルカプトエタノールを含し 
$62.5 \mathrm{mM}$ トリス塩酸楥衝液中で, $30^{\circ} \mathrm{C}, 1$ 時間振とう 抽出し、 $3000 \mathrm{rpm}$ で 10 分間の遠心分離上澄液 $1 \mathrm{ml}$ を， $100^{\circ} \mathrm{C} ， 5$ 分間加熱処理した。 ついでェッペンドル フ遠心分離を使用して $12000 \mathrm{rpm}, 2$ 分間遠心分離し て得られる上澄液 $200 \mu l$ に， $0.05 \% \mathrm{BPB}$ 含有 $70 \%$ グ リセリン水溶液 $20 \mu l$ を添加した後, LAEMMLI の方 法”に従って，8\% 濃度ゲルによる SDS-ポリアクリル アミドゲル電気泳動を行った．泳動は $100 \mathrm{~V}$ で 4 時間 行い，0.25\% クマシーブリリアントブルーにより， 40 ${ }^{\circ} \mathrm{C}, 1$ 時間染色し，エチルアルコール/酢酸/水 $(25 / 8 /$ 65）混合液中で脱染した.

\section{8. 精米粉の糊化特性試験}

第 3 項で得た精米粉を武料とし，ブラベンダー・アミ ログラフを使用して，常法に従い ${ }^{8)}$, 乾物重 $8 \%$ で糊化 特性試験を行った。

\section{9. 炊飯およひ米飯テクスチュアの測定}

第 3 項で得られた各精米（ge は91\% および 85\% 精 米) $5 \mathrm{~g}$ を用い，RANGHINO の方法 ${ }^{9}$ に従って， "minimum cooking time" (MCT) を求めた。すな わち, $230 \mathrm{~m} l$ の沸騰水中に $5 \mathrm{~g}$ の米粒を加え, 一定時 間ごとに 10 粒を採取して 2 枚のガラス板で圧着し，米 粒内部の白色未糊化部分が 9 個以上消失するのに要する 時間を求めるものである.ついで，さらに 2 分間炊飯を 続けて最適炊飯時間（OCT）に到達した炊飯米を水切 りし，ポリェチレン袋中に密封して $25^{\circ} \mathrm{C} て ゙ 1$ 時間静置 した後, 全研（株）テクスチュロメーターを使用して, 炊飯米粒 (3粒) の硬さ (H), 付着性 (A), 硬さ之付 着性の比 (H/A) を測定した。ブリッジ電圧 $2.5 \mathrm{~V}$,

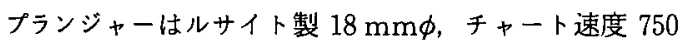
$\mathrm{mm} /$ 分, そしゃく速度 6 回/分，クリアランス 0.2 $\mathrm{mm} /$ 分の条件にて 10 回湘定し，その平均值を採択した。

\section{0. 膨化処理}

コシヒカり（水分 15.2\%），中間モ千系統 (13.9\%), 巨大胚系統 $(14.0 \%)$ ，モ千系統 $(14.0 \%)$ およびもち
ひかり (14.2\%) を試料とし，斉藤精工（有）グレンパ フマシンを使用して膨化処理を施した. $1 \times 10 \mathrm{~mm}$ の 短冊型オリフィス 6 個を有するノズルを使用し，バンド ヒーターによって $240^{\circ} \mathrm{C}$ に初期加熱した後, 玄米 $5 \mathrm{~kg}$ で予備運転を行った．玄米の膨化が定常になった後，各 武料 $2 \mathrm{~kg}$ を順次投入して膨化に供した．処理中の温度 は約 $180^{\circ} \mathrm{C}$ であった。

\section{1. 膨化度の測定}

後藤らの植物種子置換法 ${ }^{10)}$ に準じて, アオナ種子を 使用して膨化製品の比容積 $\left(\mathrm{cm}^{3} / \mathrm{g}\right)$ を測定し, 膨化度 の指標とした。

\section{2. 膨化製品の硬度の测定}

タケトモ電機（株）テンシプレッサ-TTP-50 BX を 使用して膨化製品の硬度を測定した．径 $10 \mathrm{~mm}$ のアル ミプランジャー, $20 \mathrm{~kg}$ ロードセルを使用し, 圧縮速度 $120 \mathrm{~mm} /$ 分, クリアランス $3.0 \mathrm{~mm}$ とし, 各 10 点を 測定してその平均值を採択した。

\section{3. 膨化製品の水溶性全糖}

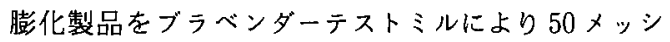
工篩通過程度に粉砕し，その $0.2 \mathrm{~g}$ に対し，蒸溜水 20 $\mathrm{m} l$ を添加し， $30^{\circ} \mathrm{C} ， 30$ 分間振とう抽出した後， 12000 $\mathrm{rpm}$ で 10 分間遠心分離して得られる上澄液を，蒸溜水 にて 50 倍に希釈し，その $1 \mathrm{~m} l$ を採取してフェノール 硫酸法 ${ }^{11)} に よ り$ 全糖量の測定を行った。

\section{結果および考察}

\section{1. 新規育成米の形質}

玄米の粒長，粒幅，粒厚および千粒重を表 1 に示す. コシヒカリ，巨大肧およびあちひかりは各測定値がよく 類似しており，典型的な短粒種である。一方，中間モ千 はやや長細く，千粒重あ少し大きい，モ千系統 $(w x)$ は，長さはもちひかりと同程度であるが，粒張りが少っ ており，その分干種重あ小さい值を示した.

表 1 新規育成米の粒長等および千粒重

(単位： $\mathrm{mm}$ )

\begin{tabular}{|c|c|c|c|c|c|c|c|c|}
\hline & 試 & 料 & 米 & 粒 長 & 粒 幅 & 粒 厚 & 粒長/粒幅 & 干 粒 重 \\
\hline כ & シ $t$ & 力 & & 4.85 & 2.92 & 2.02 & 1.66 & $20.3(\mathrm{~g})$ \\
\hline 探 & 系 1915 & $(d u)$ & （中間モチ） & 5.46 & 2.67 & 1.93 & 2.04 & 22.2 \\
\hline 探 & 系 2006 & (ge) & (巨大胚) & 5.02 & 2.98 & 1.97 & 1.68 & 20.3 \\
\hline 探 & 系 1918 & $(w x)$ & (モ千) & 5.03 & 2.63 & 1.82 & 1.91 & 17.9 \\
\hline 6 & $5 d$ & 加 1 & $b$ & 4.70 & 2.84 & 2.05 & 1.65 & 20.7 \\
\hline
\end{tabular}


表 2 新規育成米の精米試験結果

\begin{tabular}{|c|c|c|c|c|c|c|c|c|c|}
\hline & \multirow{2}{*}{ 試 } & \multirow{2}{*}{ 料 } & \multirow{2}{*}{ 米 } & \multirow{2}{*}{ 玄米白度 } & \multicolumn{2}{|c|}{ 摩擦式精米 } & \multicolumn{3}{|c|}{ 研 削 式 精 米 } \\
\hline & & & & & 1 回通し & 2 回通し & 30 秒 & 60 秒 & 120秒 \\
\hline 探 & 系 & 2006 & （巨大胚） & $\begin{array}{c}24.3 \\
(100 \%)\end{array}$ & $\begin{array}{c}42.1 \\
(84.8 \%)\end{array}$ & $\begin{array}{c}49.5 \\
(79.7 \%)\end{array}$ & $\begin{array}{c}25.5 \\
(95.2 \%)\end{array}$ & $\begin{array}{l}27.7 \\
(90.4 \%)\end{array}$ & $\begin{array}{l}36.5 \\
(87.0 \%)\end{array}$ \\
\hline 探 & 系 & 1915 & （中間モ千） & $\begin{array}{c}20.1 \\
(100 \%)\end{array}$ & $\begin{array}{c}33.1 \\
(92.5 \%)\end{array}$ & $\begin{array}{l}36.4 \\
(91.5 \%)\end{array}$ & $\begin{array}{l}25.7 \\
(94.0 \%)\end{array}$ & $\begin{array}{l}30.1 \\
(91.6 \%)\end{array}$ & $\begin{array}{c}36.3 \\
(89.1 \%)\end{array}$ \\
\hline 探 & 系 & 1918 & (モ千) & $\begin{array}{c}25.8 \\
(100 \%)\end{array}$ & $\begin{array}{c}43.1 \\
(90.7 \%)\end{array}$ & $\begin{array}{c}45.1 \\
(89.8 \%)\end{array}$ & $\begin{array}{l}27.2 \\
(96.4 \%)\end{array}$ & $\begin{array}{c}31.9 \\
(94.6 \%)\end{array}$ & $\begin{array}{c}36.1 \\
(91.4 \%)\end{array}$ \\
\hline
\end{tabular}

（注）上段の数值；ケット白度計 C-3 型による玄米および精米の白度 下段（）内の数值；精米歩留り

摩擦式精米は，サタケモーターワンパス精米機で試料 $1 \mathrm{~kg}$ を 1 回，扔よび 2 回循環。 研削式精米は，サタケテストミルで試料 $100 \mathrm{~g}$ を 30 秒〜 120 秒間精米。

\section{2. 精米試験}

新規育成米を摩擦式および研削式小型精米機によって 精米試験した結果を表 2 に示す. 巨大肧系統を摩摖式精 米した場合，一回通しでは，かなりの胚牙が残存してい るにもかかわらず，歩留りは約 $85 \%$ に低下した，二回 通しにより，肧芽はほぼ完全に除去され，精米白度も高 くなるが，歩留りは約 80\%になってしまう。研削式精 米では，歩留り $87 \%$ まで削り込んです，ほとんどの肧 芽が残存しており，白度上昇の程度も少なかった，従っ て，この米は，一般飯用米として利用するためには，摩 擦式を中心に歩留り約 $80 \%$ まで削り込むことが必要で あり，低步留りを補う意味から，肧芽，ヌカ部の有効利 用を図る必要がある，一方，栄養的観点からは，研削式 を中心に精米することにより，肧牙残存率の高い精米を 得ることができる、中間モ千系統の場合は，摩擦式，研 削式ともに，通常の飯用米に近い挙動を示し，肧芽およ びヌ力層の除去む容易であった．しかしながら，後述す る如く，胚乳部の透明度が通常米より劣るために，泼芽 およびヌカ層が同程度に除去されるにすかかわらず精米 白度が不充分と思われた。 モ千系統の場合，やや硬めで はあるが，通常米と同様の精米結果を示した。

\section{3. 透光度およひ白度}

今回試験に供したモチ系統および中間モチ系統は，モ
チ性拈よびモチ・ウルチ中間型とされているので，米粒 の透光度の点から検討を加えた，表 3 に示すごとく，玄 米, 精米ともにコシヒカリの透光度が高く，もちひかり の透光度が低い，モ千系統は，外観上，全く通常のモ千 米之区別がつかないが，透光度の点からも，あちひかり に近い值を示した，一方，巨大胚系統は，後述するごと

表 3 玄米抢よび精米の透光度および白度（単位：\%）

\begin{tabular}{|c|c|c|c|c|}
\hline \multirow{2}{*}{ 試 料 米 } & \multicolumn{2}{|c|}{ 透 光 度 } & \multirow{2}{*}{ 白 } & \multirow{2}{*}{$\begin{array}{l}\text { 度 } \\
\text { 精米 }\end{array}$} \\
\hline & 玄米 & 精米 & & \\
\hline コシヒカリ & $>100$ & 100 & 21.8 & 40.2 \\
\hline $\begin{array}{l}\text { 探采 } 1915 \\
\text { (中間乇チ) }\end{array}$ & 77 & 56 & 20.1 & 38.0 \\
\hline $\begin{array}{l}\text { 探系 } 2006 \\
\text { (巨大胚) }\end{array}$ & 27 & 27 & 24.3 & 46.6 \\
\hline $\begin{array}{lr}\text { 梁系 } & 1918 \\
(モ & f)\end{array}$ & 8 & 6 & 25.8 & 53.2 \\
\hline あちひかり & 22 & 0 & 30.2 & 52.2 \\
\hline
\end{tabular}

(注) 透光度 ; 理研計器侏 ライスメータ QS-101D 使用, 玄米については通常の設定で使用, 精米 については下限をむちひかり(0), 上限を ヨシヒカリ(100)に合わせ，拡大レンジで 相対的透光度を测定。

白 度 ; ケット科学㑣 白度計 C-3 型を使用し， 常法で測定。

表 4 新規育成米（精米）の一般成分执よびアミロース含量

(単位: \%)

\begin{tabular}{|c|c|c|c|c|c|c|c|c|}
\hline & 試 & 米 & 水 分 & 粗タンパク & 粗脂肪 & 炭水化物 & 灰分 & アミロース含量 \\
\hline$\sqsupset$ & シ $ヒ$ & 力 リ & 14.1 & 6.3 & 0.9 & 77.5 & 1.2 & 16.9 \\
\hline 探 & 系 1915 & (中間モ千) & 14.0 & 7.0 & 2.1 & 75.7 & 1.2 & 10.9 \\
\hline 探 & 系 2006 & (巨大胚) & 13.9 & 6.9 & 3.3 & 74.6 & 1.3 & 21.6 \\
\hline 探 & 系 1918 & (モ千) & 13.7 & 6.8 & 2.3 & 75.9 & 1.3 & 3.0 \\
\hline
\end{tabular}

注）試料は研削式精米（歩留り 91\%）を使用した。 
く,アミロース含量が高いにもかかわらず，透光度が低 いが，その理由は，巨大な肧芽除去部および表層部に精 白粉末が付着して透光性を著しく損っているためであり， 米粒自体は通常米と類似した透明観を有していた。 また， 白度においても，巨大胚系統はコシヒカリょりも高い值 を示した，一方，中間モ千系統の場合においては，透光 度の点ではややゥルチに近い，モチ・ウルチ中間的な值 を示したが, 白度の点では, 通常のウルチ米とほとんど 変わらない值を示した．モ千系統の場合は，透光度，白 度ともにもちひかりと類似した值を示した。

\section{4. 一般成分およびアミロース含量}

原料精米の一般成分およびアミロース含量を表 4 に示 した. 中間モ千系統，巨大胚系統，モ千系統とも，通常 米と比較して，粗脂肪含量がやや高い以外は，ほぼ類似 した成分組成であった，アミロース含量は，巨大胚系統 が最あ高く，21.6\%であり，通常の日本米よりやや高 い.コシヒカリは，従来報告されているように，16.9\% と，通常の日本米よりやや低い，モ千系統ともちひかり は，それぞれ $3.0 \% ， 2.9 \%$ ときわめて低く，中間モ千 系統の場合は, $10.9 \%$ で，奥野らの結果 $(10.5 \%)^{5)}$ 之 ほぼ一致しており，ウルチおよびモチの中間的な，きわ めて特徽的な結果を示した。

\section{5. 精米粉のタンパク質の電気泳動}

SDS およびメルカプトエタノール存在下で抽出した 米タンパク質の, LAEMMLI の方法による SDS-ポリア クリルアミドゲル電気泳動 (SDS-PAGE) の結果を,

写真 1 に示す. 各試料とも 40 以上の明瞭なバンドに分 離できたが、モ千種, ウルチ種，中間型，インディカ種 等の各種の米タンパク質の間で. SDS-PAGE パターン の類似性はきわめて高く，この方法のみからは，相互の 識別は困難と思われた。 KUSAMAらは，米タンパク質 のSDS-PAGEに銀染色法を用い，モ千種やィンディカ 種の場合に各バンド間の量比に相違の認められることを

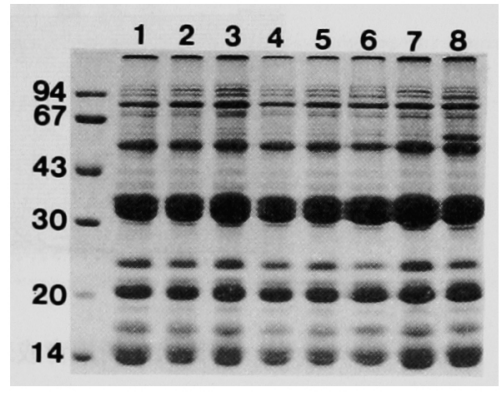

写真 1 新規育成米の SDS-ゲル電気泳動

\begin{tabular}{|c|c|}
\hline 1 ; 探系 $1915(d u)$ & 5 ; 茨城コシヒカリ \\
\hline 2 ; 探系 $1918(w x)$ & 6 ; バスマティーライス \\
\hline $\begin{array}{l}3 \text {; もちひかり } \\
4 \text { : 探系 } 2006(\sigma e)\end{array}$ & 7 ; 密陽 23 号 \\
\hline
\end{tabular}

報告しており ${ }^{13)}$ ，Guo らは，プロラミンの等電点電気 泳動により，25品種の中国産米について，モ千種，イ ンディカ種などのグループ分けが可能であると報告して いる(4)，今回の試験においては，写真に示すように，各 バンドを比較的明瞭に分離することは可能となったので, 今後さらに，タンパク質の抽出方法や染色方法の検討に より，これらの米の識別も可能になるるのと期待される.

\section{6. 精米粉の糊化特性}

茨城コシヒカリ，巨大胚系統，中間モ千系統，モ千系 統の，アミログラフィーによる糊化特性結果試験を表 5 および図 1 に示す。モチ系統の場合は，糊化温度が低く， 最高粘度が著しく低いという典型的なモ千性の糊化特 性 ${ }^{15)}$ を示した。一方，コシヒカリと巨大胚系統の場合 は，やや最高粘度が低く，ブレークダウンが小さいもの の，典型的なウルチ性の糊化特性を示した．特に興味樑 いことは，糊化特性においても，中間モ千系統が，モ千 性とウルチ性との中間的な特性を示したことであり，糊 化温度はウルチと同様に高いむのの，最高粘度はモ千と

表 5 新規育成 米の糊 化特性

(単位: Bravender Unit)

\begin{tabular}{|c|c|c|c|c|c|c|c|c|c|}
\hline & 試 & 料 & 米 & $\begin{array}{c}\text { 糊化温度 } \\
\left({ }^{\circ} \mathrm{C}\right)\end{array}$ & 最高粘度 & 最低粘度 & 最終粘度 & $\begin{array}{l}\text { ブレーク } \\
\text { ダウン }\end{array}$ & $\begin{array}{l}コ ン シ ス ~ \\
\text { テンシー }\end{array}$ \\
\hline$\sqsupset$ & シ & $t \quad t$ & 力 リ & 87.6 & 470 & 450 & 710 & 20 & 260 \\
\hline 探 & 系 & 1915( & (中間モ千) & 87.9 & 220 & 220 & 350 & 0 & 135 \\
\hline 探 & 系 & 2006( & （巨大胚） & 87.0 & 490 & 435 & 700 & 55 & 265 \\
\hline 探 & 系 & 1918 ( & (モ千) & 67.2 & 70 & 40 & 65 & 30 & 25 \\
\hline
\end{tabular}

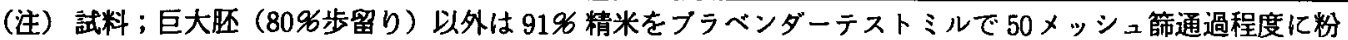
碎して使用

乾物重 $8 \%$ 


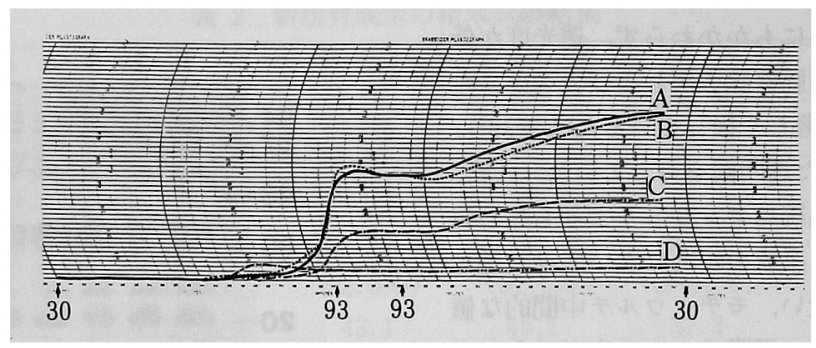

図 1 新規育成米のアミログラム

$$
\begin{aligned}
& \mathrm{A}-\text { 茨城コシヒカリ } \\
& \mathrm{B}-- \text { - }- \text { 巨大胚系統 }(\mathrm{ge}) \\
& \mathrm{C}--- \text { 中間モチ系統 }(d u) \\
& \mathrm{D}--- \text { モ千系統 }(w x)
\end{aligned}
$$

（注）試料は摩擦式精米機により歩留り $91 \%$ (巨 大狉のみ歩留り 85\%) に精白した後, ブラ ベンダーテストミルにより 50 メシュ程度 に粉砕した精米粉を使用した。

ウルチの中間であり，ブレークダウンを示さず，降温 $90^{\circ} \mathrm{C}$ 付近から二段目の粘度上昇が始まり，アミロース 含量と相関があると言われるコンシステンシー ${ }^{16)}$ あウ ルチ米の $50 \%$ 程度であった. 今回の糊化特性試験によ り, 新規育成米の糊化特性の大きな特徴は把握できたが, コシヒカリと巨大胚系統の相違が小さい点や，ブレーク ダゥンが予想より小さい点などは, 精米㸮の粒度の影響 等も考えられる ${ }^{17}$ ので. 超遠心粉砕機の使用や，デン プンによる試験等が今後の課題として挙げられる.

7. 欦飯および米飯のテクスチュア

湯だき法における MCT および米飯テクスチュア測 定結果を表 6 に示す，表には示していないが，通常の日
本米は, MCT が 17〜 18 分であり，テクスチュロメー ター特性值は,コシヒカリ等の高食味米で $\mathrm{H}$ が約 10 11，H/A が約 0.25 であり，日本晴等で $\mathrm{H}$ が 10.5 11. 5, H/A が約 0.35 0.45 である. 巨大肧系統は, 研削式精米（步留り 91\%)）之摩擦式精米（歩留り 85\%） では異なる結果が得られた，前者の場合には，MCT が やや長く，H/A がかなり高い，これは，肧芽がかなり 残存してお゙り，デンプンの吸水，糊化を妨げるためと考 えられる，一方，後者の場合には，逆に，MCT が通常 米よりやや短く, H/A は平均的汃, やや高い程度であ る.これは，精米による胚芽除去部が通常米より大きく， 吸水は速いものの, アミロース含量が比較的高いために,

表 6 新規育成米精米の MCT および米飯テクスチュア （単位：Texturo Units）

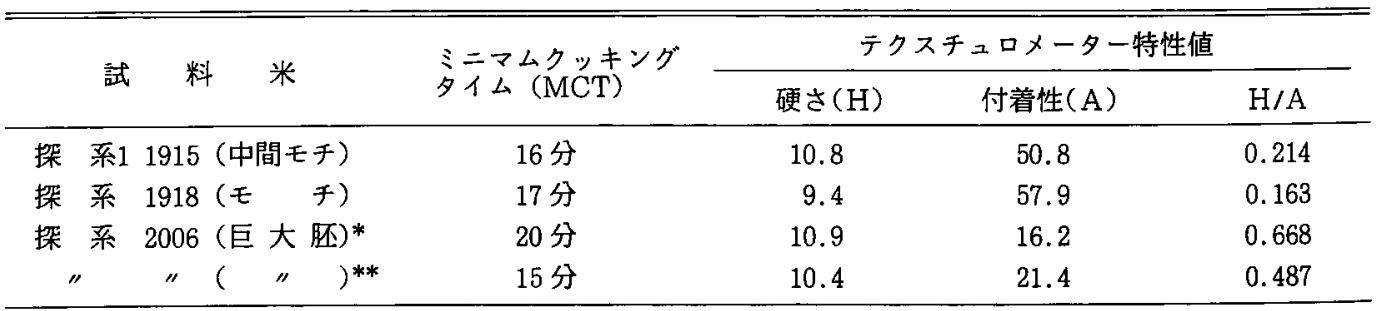

（注）試料；摩擦式精米機により步留り $91 \%$ に精米して使用（*，**を除く）。

* ; 研削式精米機により歩留り 9196 に精米して使用。

**; 摩擦式精米機により步留り $85 \%$ に精米して使用。

$\mathrm{MCT}$; 沸騰水中の米粒の 9 割以上がガラス板圧着による未糊化白色部を消失するのに要する時間 (RANGHINO の方法)。

テクスチュア測定；MCTの 2 分後に米粒を取り出し， $25^{\circ} \mathrm{C} 1$ 時間密封後，付着性強調アームを装着した 全研㑣テクスチュロメーターにより，3粒のテクスチュアを測定した。 
表 7 新規育成米の膨化試験結果

\begin{tabular}{|c|c|c|c|c|c|c|c|}
\hline & & & & & 膨化度 $\left(\mathrm{cm}^{3} / \mathrm{g}\right)$ & 硬度 (TP. U.) & 水溶性全糖 $(\%)$ \\
\hline \multirow{4}{*}{ 玄 } & \multirow{4}{*}{ 米 } & ב & シ & 七 力 リ & 6.8 & 8.6 & 21.6 \\
\hline & & 探 & 系 & 2006 (巨大胚) & 4.4 & 4.9 & 20.3 \\
\hline & & 探 & 系 & 1915 （中間モ千） & 7.1 & 6.2 & 30.9 \\
\hline & & 探 & 系 & 1918 (モ チ) & 8.1 & 4.8 & 65.0 \\
\hline \multirow{4}{*}{ 精 } & \multirow{4}{*}{ 米 } & $\sqsupset$ & シ & 七力 リ & 7.3 & 3.7 & 27.8 \\
\hline & & 探 & 系 & 1915（中間乇チ) & 8.4 & 2.9 & 33.2 \\
\hline & & 探 & 系 & 1918 (モ チ) & 8.9 & 1.8 & 85.0 \\
\hline & & $\phi$ & ち & $\circlearrowright$ 加 & 8.7 & 3.1 & 82.5 \\
\hline
\end{tabular}

（注）精 米；摩擦式精米機による精米（歩留り 91\%）を使用した。 膨化処理；斉藤精工有 グレンパフマシンを使用, 温度約 $180^{\circ} \mathrm{C}$ 。 膨 化 度; 植物種子置換法により製品の比容積 $\left(\mathrm{cm}^{3} / \mathrm{g}\right)$ を測定。 硬度；タケトモ電機儆テンシプレッサーTTP-50 BXにより測定。

水溶性全糖; 蒸溜水で抽出後, $12000 \mathrm{rpm}$ の遠心分離上澄液中の全糖量をフェノール硫酸法により測定。

H/A がやや高くなっているものと推察される。モ千系 統の場合は，MCT は平均的值であるが，付着性がきわ めて大きく，H/A は小さくなっている，中間モ千系統 の場合は，MCT がやや短く，モ千系統ほどではないむ のの, 通常のウルチ米と比較して, 付着性が大きく, H/A が小さい值を示した. 中間モチ系統単独で炊飯し た場合は，やや粘りが強すぎるすのの，一般飯用米に一 定の割合添加して炊飯する場合には，全体の米飯の食味 向上に寄与するものと推察される.

\section{8. 膨化試験結果}

膨化試験結果を表 7 に示した，膨化度においては，巨 大肧系統の玄米で低く，中間モ千系統およびモ千系統は 良好であった．巨大胚系統の玄米は，八トムギの膨化性 における傾向 ${ }^{18)}$ と同様に，脂肪含量が高いことによる 膨化不良を生じたためと推察される，柳瀬ら ${ }^{(9)}$ の報告 によると，モチ米の場合，ウルチ米に比べて，膨化製品 の霜ざわりが軽く，膨化度も優れているが，水溶性全糖 の増加が著しいという。このため，スナック食品として は，歯に付着しやすく，食味を損なうことになる，命回 の試験においても，あちひかりおよびモ千系統の場合に この傾向が現れ，スナック食品よりはむしろ，液状食品， スープ素材上して適していると推察された，中間モチ系 統の場合は，膨化度す良好であるばかりでなく，精米膨 化製品の硬度む低く，食感がンフトであった，さらに， 水溶性全糖が，ウルチ米の約 $20 \%$ よりは多いすのの, 約 $33.2 \%$ と，モ千米の $80 \%$ 以上という值と比較して非 常に低く, 中間型か，むしろウルチ性に近い值であった。 こうした点から，中間モチ系統の精米の膨化製品は，新
しい米菓, スナック食品等の用途に好ましい特徴を有し ていると考えられた。

\section{要 約}

（1）新しく育成された 3 系統の有する新規形質，巨大 胚 $(g e)$ ，中間モ千 $(d u)$ ，モ千 $(w x)$ の利用特 性試験を行った。

(2) LAEMMLI の方法に従い，SDS-PAGE による各 品種間の識別を試みた，精米のタンパク質を 40 以上の明瞭なバンドに分離できたが，相互の類似 性が高く，これを系統行類等に利用するためには， さらに染色法や分画法の検討が必要と思われた。

（3）巨大肧系統は，胚が大きく，粗脂肪含量が高い. 研削式精米では，胚芽残存率が高いので，肧芽精 米としての利用が考えられる，摩擦式精米では， 还芽が完全に除去されるが，歩留まりは約 $85 \%$ に低下した．アミロース含量は $21.6 \%$ とやや高 く，膨化性，米飯テクスチュアの点では，やや硬 いウルチ米に近い傾向を示した。

（4）モ千系統は，外観および諸性質が通常のモチ米に きわめて近く，膨化によってデンプンが可溶化す るので，液状食品等の用途に適していると考えら れた。

（5）中間モ千系統は，アアミロース含量が $10.9 \%$ とモ チ・ウルチの中間であり，透光度がやや低い，米 飯テクスチュアでは，付着性が大きく，H/A が 小さいというモチ性に近い傾向が認められた，糊 化特性では，糊化温度がウルチに近いものの，最 
高粘度，ブレークダウン等がウルチの約 50\%で あった．膨化性が良好で水溶性全糖の増加も少な く、スナック食品等の用途に適していると考えら れた。

\section{文献}

1) 本松 周：米穀の流通と管理 (地球社, 東京), p. 13 (1985).

2）中川原捷洋：稲と稲作のふるさと（古今書院，東 京) p. 1 (1985).

3) Nakagahra, M., Nagamine, T. and OKuno, K.: Annual Report of National Institute of Agrobiological Resources, No. 1, 15 (1985).

4) 大村 武- 佐藤 光: 育種学最近の進歩, 第 22 集, p. 10 (1981).

5) OKuno, K., Fuwa, H. and Yano, M. : Japan J. Breed., 33, 387 (1983).

6) Juliano, B.O. : Cereal Sci. Today, 16, 334 (1971).

7) LaEmmLi, U.K.: Nature, 227, 680 (1970).

8）谷 達雄・吉川誠次・竹生新治郎・堀内久弥・遠 藤 勲・柳瀬 肇: 栄養と食糧, 22, 452 (1969).

9) Ranghino, F.: Riso, 15, 117 (1966).
10）後藤富士雄 : 澱粉科学実験法（朝倉書店，東京） p. 177 (1979).

11) Dubois, M., Gilles, K.A., Hamilton, J.K., Rebers, P.A. and Smith, F.: Anal. Chem., 28, 350 (1956).

12) Juliano, B.O.: Rice (American Association Cereal Chemists, Minnesota), p. 60 (1985).

13) Kusama, T., Yanagi, S.O. and Iwamoto, M. : Agric. Biol. Chem, 48, 1649 (1984).

14) Guo, Y.J., Bishop, R., Ferhnstrom, H., YU, G.Z., LIAN, Y.N. and HUANG, S.D.: Cereal Chem., 63, 1 (1986).

15）木原芳次郎・暒川靖子：農産加工技術研究会誌， 7, 155 (1969).

16) Juliano, B.O.: Rice (American Association of Cereal Chemists, Minnesota) p. 482 (1985).

17）斉藤昭三：没粉科学, 27，295（1980）。

18）大坪研一・柳瀬 肇・橋本勝彦・豊島英親・戸谷 昭夫：日食工誌, 31, 596 (1984).

19）柳瀬 肇・遠藤 勲・渋谷直人・大坪研一：食総 研報, No. 41，39 (1982)。

(昭和 62 年 6 月 15 日受理)

Developments in Food Microbiology-3

\section{R.K. Robinson 編}

前 2 巻に引き続き, 食品微生物に関する最近の話題が 収められている.内容は，ビールの变敗原因微生物, 組 織培養: 技術之可能性, 発酵野菜中の乳酸菌, 発醅プロ セスの経済性, 液体培養によるセルロースおよび部分可 溶化植物体の生物变換の可能性, 食品加害系状菌の分類 の最近の進歩，紫外線による水の净化である.

食品産業の研究者，技術者の参考書として最適である．

$23 \times 14.5 \mathrm{~cm}, 198$ 頁, 34 ポンド

Elsevier Applied Science Publishers, Ltd., London Crown House, Linton Road, Barking, Essex, IG 118 JU England 